VI. Полемічна трибуна

УДК $821.111^{\prime} 04$

DOI: https://doi.org/10.32840/2225-479X.2019.31-32.15

\author{
Корнелюк Богдан \\ (Запоріжжя)
}

\title{
I, in this weak piping time of peace: перший монолог шекспірівського Річарда III як маніфест кризи ідентичності
}

У статті здійснено аналіз інтенціональних актів Річарда Глостера, зафіксованих у тексті першого монологу протагоніста. На початку п'єси персонаж із тугою згадує час збройного протистояння Йорків і Ланкастерів. Ностальгічність Річарда пояснюється тим, що в умовах війни він мав иілісну ідентичність $і$ виступав в іпостасі воїна. Специфічна аксіологічна парадигма воєнного часу дозволяла йому безкарно чинити злодіяння, які до того ж були мотивовані високою метою - перемогою у битві та у війні загалом. $B$ ией час формується інтенційне ядро протагоніста, яке вподальшому $i$ визначатиме його поведінку. Основні риси його інтенційності іманентна жорстокість, рішучість, бажання перемагати будь-якою ціною, звитяжність та схильність до стратегічних розрахунків.

В мирний час іпостась Річард-воїн не може бути реалізована, тож протагоніст опиняється у кризовій ситуачії. Він починає структуррування нової ідентичності, що могла б співіснувати із рисами його інтенційності, сформованими у воєнний час. Інтенщійність Річарда включає іманентний потяг до злодіянь, тож персонаж логічно обирає для себе іпостась негідника. Однак Глостер звик творити зло лише тодi, коли воно мотивоване певною великою ціллю. Такою метою для протагоніста стає здобуття англійського престолу. Для того, аби інтегруватися у придворне життя, персонаж використовує ще одну грань своєї інтенційності - від природи він наділений даром перевтілення. Тож іпостась Річард-негідник актуалізується у п'єсі у зв'язиі із іпостассю Річард-актор. При иьому талант військового стратега протагоніст застосовує для иілей мирного життя, вибудовуючи стратегію сходження на престол. 
Корнелюк Богдан. I, in this weak piping time of peace: перший монолог ...

Ключові слова: Шекспір, Річард III, ідентичність, інтенціональність, криза, іпостась.

Центральний образ історичної хроніки «Річард III» вражає своєю амбівалентністю. 3 одного боку, він постає таким собі генієм злодійства - кривавим тираном, що за масштабністю злочинів може зрівнятися 3 біблійним Іродом, за віроломством - 3 Іудою, а за підступністю задумів - із самим дияволом. 3 іншого боку, Річард III це багатогранний образ рефлектуючої людини-актора i людини-режисера, що невідступно чинить зло, але, тим не менш, викликає емпатію глядачів.

Доволі розлогим $\epsilon$ перелік праць, присвячених висвітленню образа Глостера на тлі тогочасних ідеологічних, історіософських та естетичних конвенцій. Так, Г. Грейді ${ }^{1}$, Дж. Роу ${ }^{2}$, Т. Спікерман ${ }^{3}$, М. Барг ${ }^{4}$, В. Комарова ${ }^{5}$ аналізують образ протагоніста в контексті макіавеллізму, Л. Пінський ${ }^{6}$, I. М. Тілльярд ${ }^{7}$ зосереджують увагу на особливостях репрезентації в хроніці усталених уявлень про кореляцію тілесності і внутрішнього світу людини, а О. Анікст ${ }^{8}$ К. Блекні ${ }^{9}$ Т. Куллман ${ }^{10}$, О. Смирнов ${ }^{11}$,

${ }^{1}$ Carnall G. Shakespeare's Richard III and St. Paul // Shakespeare Quarterly. 1963. - Vol. 2. - P. 186-188.

${ }^{2}$ Roe J. A. Shakespeare and Machiavelli. - Cambridge : D. S. Brewer, 2002. $216 \mathrm{p}$.

${ }^{3}$ Spiekerman T. Shakespeare and Machiavelli Revisited / Shakespeare's Political Realism : The English History Plays. - New York : State University of New York Press, 2001. - P. 153-166.

${ }^{4}$ Барг М. А. Шекспир и история. - М. : Наука, 1976. - 199 с.

${ }^{5}$ Комарова В. П. Макьявелли и макьявеллизм в некоторых английских драмах эпохи Шекспира / Проблемы культуры итальянского Возрождения. - Л. : Наука, 1979. - С. 93-105

${ }^{6}$ Пинский Л. Е. Шекспир : Основные начала драматургии. - М. : Художественная литература, 1971. - 607 с.

${ }^{7}$ Tillyard E. M. W. Shakespeare's History Plays. - Edinburgh : Peregrine Books, 1962. $-336 \mathrm{p}$.

${ }^{8}$ Аникст А. А. Эволюция драматической речи в хрониках и трагедиях Шекспира // Шекспировские чтения. - М. : Наука, 1990. - С. 7-54. 


\section{VI. Полемічна трибуна}

А. Степковська ${ }^{12}$ і Ю. Шведов ${ }^{13}$ детально досліджують так звані «проблемні сцени» цього Шекспірового твору (до яких відносять епізоди зваблення леді Анни, вигнання Бекінгема та фінал п'єси). У західному літературознавстві досить поширеною $\epsilon$ думка, що образ Глостера, створений великим драматургом, має чітко виражений релігійний підтекст. Так вважають, приміром, I. Рібнер $^{14}, \quad$ Е. Гаммонд ${ }^{15}$, Д. Бівінгтон ${ }^{16}, \quad$ М. Крігер ${ }^{17}$, Дж. Карналл ${ }^{18}$ та ін.

Вельми перспективним і продуктивним у науковому плані бачиться перенесення дослідницького фокусу iз контекстуально-дискурсивної сфери у стихію образноантропологічну. Головний персонаж хроніки наділений рельєфно виписаною фікціональною свідомістю, що може стати продуктивним об'єктом інтенціонального

${ }^{9}$ Blakeney K. William Shakespeare's Richard III : Brilliant Schemer, Entertaining Villain // Student Pulse. - 2010-2(01).

URL : http://www.studentpulse.com/a?id=118.

${ }^{10}$ Kullman T. Shakespeare and Peace // Shakespeare and War / [ed. by R. King and P. Franssen]. - London : Palgrave Macmillan, 2008. - P. 43-55.

${ }^{11}$ Смирнов A. А. Ричард III // Шекспир В. Полное собрание сочинений: в 8 т. / В. Шекспир; [под ред. А. А. Смирнова]. - М. : Художественная литература, 1957. - Т. 1. - С. 610-637.

${ }^{12}$ Stepkowska A. Wooing-Scenes in "Richard III" : A Parody of Courtliness? // Styles of Communication. - 2009. - Vol. 1. - P. 1-5.

${ }^{13}$ Шведов Ю. Ф. Вильям Шекспир. Исследования [под ред. Я. Н. Засурского]. - М. : Изд-во Московского университета, 1977. - 394 с.

${ }^{14}$ Ribner I. The English history play in the age of Shakespeare. - London : Routledge Library, 2005. - P. 23.

${ }^{15}$ Hammond A. Introduction to the Arden edition of the works of William Shakespeare // Shakespeare W. King Richard III / W. Shakespeare ; [ed. by A. Hammond]. - London, New York : Routledge, 1990. - P. 109.

${ }^{16}$ Bevington D. Introduction to "Richard III" // Shakespeare W. Richard III / W. Shakespeare ; [ed. by D. Bevington, D. Kastan]. - New York: Bantam Classic, 2006. - P. 7-78.

${ }^{17}$ Krieger $M$. The Dark Generations of "Richard III" // Criticism. - 1959. Vol. 1. - No. 1. - P. 35.

${ }^{18}$ Carnall G. Shakespeare's Richard III and St. Paul // Shakespeare Quarterly. 1963. - Vol. 2. - P. 187/ 
аналізу. Тож мета статті полягає у виявленні поетологічної специфіки структурування Річардової ідентичності шляхом аналізу предметно-смислового універсуму першого монологу хроніки крізь призму інтенціональних актів протагоніста. Варто також зауважити, що розгляд літературних героїв як особистостей, які наділені унікальною свідомістю, суголосний ідеям антропологізму однієї 3 найвпливовіших течій у сучасному літературознавстві.

Саме інтенційність, тобто зафіксованість інтенцій персонажа у тексті, дозволяє передбачати ту модальну рамку, в просторі якої буде здійснюватися інтенціональне конструювання будь-якого феномену свідомості, а отже і ставлення героя твору до такого феномену. Текстова зафіксованість надає певної об'єктивності цій інтенційності, висновки про яку можна робити, проаналізувавши інтенціональні акти, які відбуваються у свідомості персонажа та відображені в тексті. Використання в процесі інтерпретації першого монологу Глостера теорії ідентичності із залученням інтенціонального підходу та стратегї «closereading» дозволяє розкрити додаткові або приховані смисли художнього тексту, що і визначає наукову новизну розвідки.

Уже вступний солілоквій хроніки вводить реципієнтів безпосередньо в лабораторію похмурих задумів протагоніста, де інтенціональні акти набувають вербального втілення. Припинення воєнних дій позбавляє головного героя його звичної іпостасі - Річард-воїн - i знаменує кризу ідентичності персонажа. В рамках цього солілоквію відбувається інтенціональне конструювання оновленої самості Річарда Глостера в ситуації миру, яка для нього $є$ незвичною. Нова поствоєнна ідентичність персонажа вже не є цілісною, вона постає як складний продукт взаємодії одразу декількох іпостасей. Саме у першому солілоквії хроніки відбувається кристалізація 


\section{VI. Полемічна трибуна}

тих ключових іпостасей протагоніста, які в подальшому визначатимуть перебіг інтенціональних актів персонажа.

Повоєнна реальність характеризується Річардом як "weak piping time of piece». ${ }^{19} \mathrm{y}$ цій фразі маємо прикметник «weak» (слабкий), що експліцитно наділений негативною семантикою. Негативні конотації переходять і на наступний за ним атрибутив - «piping» (той, що грає на дудці чи волинці). Цей прикметник повинен створити асоціації із дудкою або ж пасторальною волинкою шотландським інструментом, який має м'який мелодійний звук. Для вуха Річарда таким звукам бракує сили, вони слабкі, особливо якщо їх порівнювати iз військовими маршами, що також згадуються у цьому солілоквії («dreadful marshes»). Мирне існування наповнене, на думку персонажа, «лінивими насолодами» («I am determined to prove a villain, / And hate the idle pleasures of these days» ${ }^{20}$ ). Словосполучення «these days» iз цього пасажу та фраза «weak piping time of piece» характеризують один i той же часовий проміжок мирний період позірного благополуччя, що послідував за перемогою Йорків у війні Троянд, тобто час, коли починається дія п’єси.

Річард відкрито постулює експліцитну ненависть до інтенціональної предметності поствоєнної доби, об'єднаної родовим поняттям «idle pleasures of these days», в якому часовий відтинок «these days» відповідає темпоральному атрибутиву «weak piping time of piece». $\mathrm{Y}$ солілоквії наявні і видові репрезентанти (втілення) фрази-гіпероніму «idle pleasures of these days». Це, приміром, «merry meetings», «delightful measures», «lascivious pleasing of a lute», "fair well-spoken days»,

\footnotetext{
${ }^{19}$ Shakespeare W. King Richard III // The Arden edition of the works of William Shakespeare; [ed. by A. Hammond]. - London, New York : Routledge, 1990. P. 126.

${ }^{20}$ Ibid. - P. 127.
} 
«amorous looking-glass». ${ }^{21}$ Незважаючи на те, що протагоніст вкрай негативно сприймає інтенціональну предметність мирного часу, він наділяє іï вишуканими епітетами 3 виразним позитивним звучанням (merry, delightful, lascivious, fair, well-spoken, amorous, nimbly). Тут маємо перший випадок Річардової іронії, яка $\epsilon$ своєрідним модусом персонажа, що детермінує його схильність до чорного гумору. Із цього ж пасажу можна вивести ще два модуси інтенційності Глостера - це ненависть до прекрасного, а також відраза до всього, що не мотивоване певною ціллю, як-то безглузді розваги. Саме актуалізація останніх двох модусів призводить до того, що персонажа відштовхує гармонія, яка знаходить вияв у музиці (lascivious pleasing of a lute, delightful measures) або ж танцях (he capers nimbly), йому не подобаються придворні зібрання (merry meetings), його не вражають тілесна краса чи любовні ігри (amorous lookingglass), так само як і пишномовність оточення (fair wellspoken days).

$\mathrm{y}$ пасажі «... And hate the idle pleasures of these days» 22 особливу увагу слід звернути на епітет «idle», котрий можна перекласти як лінивий та бездіяльний. Мирний час бачиться Річардові добою апатії та застою: люди, які оточують протагоніста, не прагнуть нових звершень, бажаючи лише «лінивих насолод». Повоєнна буденність характеризується цікавою метафорою:

And all the clouds that lour'd upon our House

In the deep bosom of the ocean buried. ${ }^{23}$

Глибоке лоно моря виступає тут символом крайнього застою - в той час як у верхніх шарах морів та океанів відбувається постійний обмін водяних мас, води глибинних шарів майже не переміщуються та мають

\footnotetext{
${ }^{21}$ Ibid.

${ }^{22}$ Ibid.

${ }^{23}$ Ibid. - P. 125.
} 


\section{VI. Полемічна трибуна}

стабільну температуру незалежно від пори року. Річарда відштовхує статика повоєнної реальності. Основний імператив мирного існування - збереження того, що вже здобуто - суперечить діяльнісній паненергійній натурі протагоніста. Про іманентне прагнення діяти свідчить, зокрема, пасаж, в якому Глостер відкрито говорить про те, що смерть Едварда дасть йому, нарешті, можливість привносити суєту у світ: "And leave the world for me to bustle in». ${ }^{24}$ Семантика дієслова «to bustle», використаного Річардом, показує масштаб його руйнівного запалу, а також природну схильність майбутнього короля до рішучих дій та активності. У фразі «Now are our brows bound with victorious wreaths» ${ }^{25}$ Глостер, як думається, невипадково використовує дієслово «bound», що, окрім значення «обв'язувати», має ще і значення «зв'язувати», «заковувати». У переможних вінках персонаж вбачає окови, які обмежують його свободу дій.

Що ж є противагою «слабкого миру»? Це, передусім, війна і ¥і атрибути, які згадуються у солілоквії «bruised arms», «stern alarums», «dreadful marshes», «barbed (armed for war) steeds». Війна виступає у тексті хроніки антитезою амурних розваг («delightful measures») та веселощів («merry meetings»), що супроводжуються танцями («He capers nimbly in a lady's chamber») i музикою («To the lascivious pleasing of a lute»). Усi згадані об'єкти, об'єднані військовою тематикою, слід розглядати як інтенціональні феномени Річардової свідомості, які наділяються позитивними конотаціями. Вони характеризують для героя добрі старі часи, за якими він відверто ностальгує. В солілоквії атрибути воєнної дійсності, що наділяються позитивною семантикою, антитетично протиставляються інтенціональним

\footnotetext{
${ }^{24}$ Ibid. - P. 157.

${ }^{25}$ Ibid. - P. 125.
} 
предметам зі сфери миру, які персонаж клянеться ненавидіти.

Позитивне ставлення Річарда викликають не лише матеріальні об'єкти, але і емотивні вияви, пов'язані із військовим протистоянням, зокрема, страх. У невеликому за обсягом уривку вступного солілоквія лексеми, пов'язані із почуттям переляку, використовуються тричі (dreadful marshes; To fright the souls of fearful adversaries). Слід зауважити, що про війну протагоніст говорить як про таке собі божество чоловічого роду, використовуючи при цьому уособлення ( "Grim visag'd War hath smooth'd his wrinkled front» ${ }^{26}$ ) та онімізуючи апелятив «war». Вiн обожнює війну, бо в часи протистоянь міг бути самим собою, реалізуючи свою іманентну іпостась - Річардвоїн.

Натомість у мирний час Річард переживає катастрофічну для себе зміну - втрату власної ідентичності, яка сформувалася та успішно функціонувала в умовах затяжної війни Білої та Червоної троянд. Вперше у своєму житті протагоніст стикається із ситуацією, коли необхідність воювати відсутня. Така зміна екзистенціальної парадигми породжує кризу ідентичності, яка знаходить своє відображення у тексті хроніки. Так, у другому рядку першого Річардового солілоквія присутній каламбур:

Now is the winter of our discontent

Made glorious summer by this son of York. ${ }^{27}$

Багатозначність реалізується тут завдяки використанню іменника «Son» (син), який є омофоном із лексемою «sun» (сонце). Говорячи про сина Йорків («this son of York»), Річард може мати на увазі свого брата, короля Едварда, який є тим «сином Йорка», що на початку п’єси

\footnotetext{
${ }^{26}$ Ibid. - P. 126.

${ }^{27}$ Ibid. - P. 125.
} 


\section{VI. Полемічна трибуна}

носить титул англійського монарха. Можливим є й інше прочитання - Річард використовує вказівний займенник «this», говорячи у цьому пасажі про самого себе. Саме він $\epsilon$ тим сином Йорків, що перетворив зиму війни на літо миру. Під таким кутом інтерпретації у словах Глостера вчувається незадоволеність фактом королювання Едварда. Далі в тексті протагоніст хроніки згадує, що тяжко працював задля сходження на престол брата: "I was a pack-horse in his great affairs; / A weeder-out of his proud adversaries, / A liberal rewarder of his friends: / To royalize his blood I spilt mine own»" "28 was too hot to do somebody good/That is too cold in thinking of it now» ${ }^{29}$ ). Втім, виявилося, що зусилля персонажа не були віддячені належним чином, і в новому мирному світі він залишився ні $з$ чим, тоді як його брат зійшов на англійський престол.

Bapiaнт «this sun of York» (це сонце Йорка) має, як думається, викликати асоціації із королівською емблемою короля Едварда IV - сонцем (у третій частині Шекспірового «Генріха VI» згадується, що Едвард обрав своїм символом сонце, побачивши три сонця перед переможною для нього битвою під Мортімер Кросс). Втім, цей варіант прочитання може стосуватися і Річарда. Думається, що Шекспір невипадково використовує антитезу «зима звад - літо світлодайне» (winter of our discontent - glorious summer). Саме влітку день $є$ найдовшим, а у світлі сонця всі недоліки зовнішності Річарда виявляються ще помітнішими. Крім того, протягом довгого сонячного дня повітря значно прогрівається, а за таких умов некомфортно носити багато одягу. Тож влітку Глостер позбавлений можливості приховати свої фізичні вади навіть за допомогою вбрання. До речі, у цьому монолозі зустрічаємо ще одну згадку про сонце:

Why, I, in this weak piping time of peace,

\footnotetext{
${ }^{28}$ Ibid. - P. 158.

${ }^{29}$ Ibid. - P. 168
} 
Have no delight to pass away the time,

Unless to spy my shadow in the sun

And descant on mine own deformity. ${ }^{30}$

Можливе символічне прочитання аналізованого пасажу - в час «літа Йорків» (мирного існування - «weak piping time of peace»), коли все навколо потопає $\mathrm{y}$ блискучому сонячному світлі (маються на увазі придворні розваги), Річард не знаходить собі місця. Сонячні промені яскраво демонструють всі недоліки зовнішності протагоніста. Він свідомо уникає дзеркал («But I, that am not shape'd for sportive tricks, / Nor made to court the amorous looking glass» ${ }^{31}$ ), втім, потрапляючи під сонце, він змушений бачити свій потворний силует у вигляді тіні. При цьому Глостер немовби дистанціюється від власної тіні: він використовує дієслово «spy», що означає «підглядати», «шпигувати» - на свій відразливий силует він дивиться нібито як сторонній споглядач. Крім того, лексема «spy» має також викликати асоціації із придворними інтригами, які, за логікою, мали активізуватися, коли після воєнного лихоліття запанував мир.

Водночас, правомірною є й інша інтерпретація цього пасажу - у світлі блиску мирного часу сам Річард перетворився на тінь. В такому разі словосполучення «my shadow» (моя тінь) означає не фактичне відображення, а ту екзистенціальну кризу, яку переживає протагоніст. Втративши свою ідентичність в рамках звичної іпостасі Річард-воїн, герой перетворився на тінь самого себе. Мирний час унеможливлює реалізацію його військових амбіцій, до того ж його не цікавлять безглузді придворні забави (узагальнені дієсловами «spy» i «discant» та фразою «idle pleasures of these days»). Отже, в час проголошення першого солілоквію Річард має нульову

\footnotetext{
${ }^{30}$ Ibid. - P. 126, 127.

${ }^{31}$ Ibid. - P. 126.
} 


\section{VI. Полемічна трибуна}

ідентичність, а тому на часі постає віднайдення чи ж конструювання «нового себе».

Наприкінці солілоквію Річард визначається із своєю основною іпостассю: "I am determined to prove a villain, / And hate the idle pleasures of these days». ${ }^{32}$ Слід зауважити, що іпостась Річард-негідник - це природна грань його ідентичності, яка протягом всієї п’єси структурує ядро інтенційності цього персонажа. Він не сприймає красу та гармонію, йому подобається творити зло, він отримує задоволення, сіючи горе та руїну. Персонаж зізнається, що вже почав реалізовувати цю інтенційність:

Plots have I laid, inductions dangerous, By drunken prophecies, libels and dreams,

To set my brother Clarence and the king

In deadly hate the one against the other. ${ }^{33}$

Втім, для Річарда злодіяння є не лише джерелом гедоністичного задоволення. Будь-яке зло, вчинене ним, має ще й своєрідну точку прикладання, певний легітимізуючий мотив. Таким мотивом для Річарда-негідника стає амбітна мрія про здобуття англійської корони. При цьому напрацьована за часів війни здатність до планування та розрахунку стає в нагоді протагоністові i в мирний час - завдяки їй він перетворюється на особливо небезпечного негідника-стратега, що чітко вираховує кожен свій крок. Ставши монархом, протагоніст планує помститися своєму оточенню за нанесені образи, та водночас, у повній мірі насолодитися владою, яка дозволить безкарно чинити злодіяння. Королівський титул стає своєрідною метою і вектором розгортання життєвої стратегії персонажа, постійно підживлюючи його активність.

\footnotetext{
${ }^{32}$ Ibid. - P. 127.

${ }^{33}$ Ibid.
} 
Для досягнення омріяного трону Шекспірів герой поєднує природну іпостась Річіард-злодій із ще однією іманентною гранню своєї натури - Річард-актор. Протагоніст має вроджену здатність до лицедійства, тож йому вдається блискуче перевтілюватися. Іпостась Річард-актор реалізується одразу у двох напрямках. Перший - це, власне, взаємодія з іншими персонажами, в ході якої герой змінює численні маски-амплуа (звабник; родичбрат, син, дядько; потвора; «макіавель» тощо). Другий же напрямок знаходить свій вияв у солілоквіях та репліках убік, в рамках яких Річард здійснює вибір масок-амплуа для певного епізоду, хизується своїми успіхами, або ж жартує із притаманною йому похмурою іронією. Реципієнтами цієї акторської гри мають стати глядачі/читачі. Річард оприявнює генезу власних задумів, тобто фактично розкриває перед публікою перебіг власних інтенціональних актів. Він немовби втягує глядачів/читачів у світ своїх жорстоких рефлексій. Завдяки цьому між протагоністом і аудиторією виникає зв'язок особливого типу: попри всю ницість i аморалізм вчинків Річарда реципієнти інколи відчувають співчуття до цього персонажа i навіть не можуть уникнути певного захоплення його окремими рисами. 